\title{
Palladium-Catalyzed Asymmetric Carboamination of Alkenes
}<smiles></smiles><smiles>[NH2+]=Nc1ccccc1</smiles>

$\mathrm{Pd}(\mathrm{OAc})_{2}(4 \mathrm{~mol} \%)$ (S) $-t-\mathrm{BuPHOX}(10 \mathrm{~mol} \%)$

(0.1 mmol)

(1.2 equiv)
$t$-BuOLi (1.4 equiv)

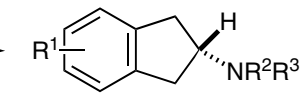

$\mathrm{PhMe}, 95^{\circ} \mathrm{C}, 3-16 \mathrm{~h}$

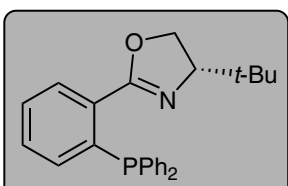

(S)- $t$-BuPHOX

Proposed stereochemical model:<smiles>CC=CCc1ccccc1O</smiles><smiles>[2H]C(=O)c1ccccc1CNCCN</smiles><smiles>C#CC1CCCCC1</smiles><smiles>[2H]C1Cc2ccccc2C1[NH3+]</smiles>

anti-aminopalladation

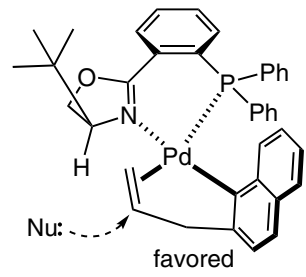

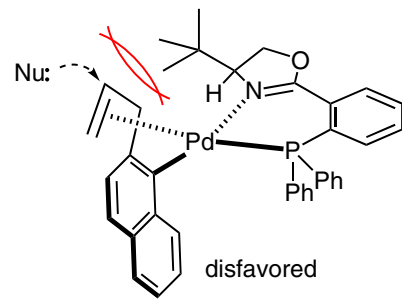

Selected examples:

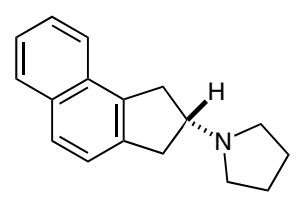

$95 \%$ yield, $98 \%$ ee (1.0 mmol scale)

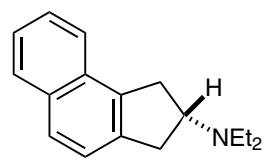

$47 \%$ yield, $78 \%$ ee

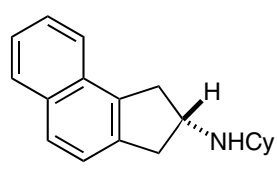

$63 \%$ yield, $>98 \%$ ee<smiles>CCN[C@H]1Cc2ccc3ccccc3c2C1</smiles>

$82 \%$ yield, $94 \%$ ee<smiles>c1ccc2c3c(ccc2c1)C[C@H](N1CCOCC1)C3</smiles>

$88 \%$ yield, $90 \%$ ee<smiles>COc1ccc2c(c1)C[C@@H](N1CCCC1)C2</smiles>

$56 \%$ yield, $94 \%$ ee<smiles>c1ccc2c3c(ccc2c1)C[C@H](N1CCCCC1)C3</smiles>

$90 \%$ yield, $90 \%$ ee

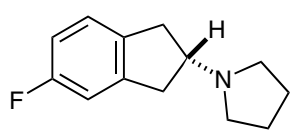

$77 \%$ yield, $96 \%$ ee
Significance: The authors presented an asymmetric alkene carboamination reaction that uses an external amine nucleophile. A combination of a palladium(II) salt and the (S)-t-BuPHOX ligand worked efficiently to deliver 2-aminoindane derivatives in high yields and excellent enantioselectivities (>98\% ee).
Comment: The intermolecular anti-aminopalladation with an external amine nucleophile is the major highlight of this work. This group previously reported an intramolecular anti-aminopalladation for the synthesis of cyclic sulfonamides (Chem. Eur. J. 2014, 20, 8782). A deuterium-labelling study supported the anti-aminopalladation pathway. The choice of the chiral ligand and nucleophile are crucial for high yields and selectivities.

SYNFACTS Contributors: Hisashi Yamamoto, Ramesh C. Samanta 